\title{
SILICA NANOPARTICLES FOR BIOMEDICAL APPLICATION: CHALLENGES AND OPPORTUNITIES
}

\author{
Mun E.A. ${ }^{1}$, Zhaisanbayeva B.A. ${ }^{2}$ \\ ${ }^{1}$ National Center for Biotechnology, \\ 13/5, Korgalzhyn road, Nur-Sultan, 010000, Kazakhstan \\ ${ }^{2}$ School of Engineering, Nazarbayev University, \\ 53, Kabanbay Batyr ave., Nur-Sultan, 010000, Kazakhstan \\ ellina.moon@gmail.com
}

\begin{abstract}
Over the past few decades, nanoparticles have been attracting significant attention of researches in chemical, biomedical, pharmaceutical sciences, due to their unique physicochemical properties. This includes ultra small size, large surface area, good biocompatibility and high reactivity. In particular, nanoparticles are promising for pharmaceutical and biomedical fields, as they can be applied as drug carriers and diagnostic tools. Among nanomaterials for biomedical application, silica nanoparticles exhibit great potential due to their straightforward synthesis and separation, low cost, safety, biocompatibility and possibility to further functionalization. Silica nanoparticles have been attractive for pharmaceutical science due to their unique properties, such as tunable size, high surface area and large pore volume, and potential in biomedical application as drug and gene delivery vectors and bioimaging agents. However, some of their properties remain poorly investigated. This short communication discusses the main routes for synthesis of silica nanoparticles, their properties and opportunities for their application in pharmaceutical and biomedical industries, as well as a few challenges in the development of silica-based systems that need to be overcome.
\end{abstract}

Keywords: silica, nanoparticles, drug delivery, gene delivery, biomedical application

\section{INTRODUCTION}

Nanoparticles (NPs) have significant potential for biomedical application due to their unique physicochemical properties, including their ultra small size, high reactivity and large surface area to mass ratio which can offer significant benefits compared to traditional therapeutic and diagnostic agents [1]. Due to these reasons, nanoparticles have been attracting considerable interest in biomedical and pharmaceutical sciences over the last two decades [2]. They have been successfully applied as drug carriers [3], diagnostic tools [4], labelling and tracking agents [5]. A large group of inorganic nanomaterials for biomedical application have been described, including gold, titanium, iron oxide and silica. Whilst gold has been widely explored and has a long history of use, silica nanoparticles are less well defined but appear promising and are the subject of recent investigations for drug delivery [6].

Silicon is the second (27.2\%) most common element presented in the crust after oxygen (45.5\%) [7]. Due to its physical and chemical properties, silicon and its oxide forms are employed in various industries, including biomedical. The interest of silicon dioxide (silica) based nanoparticles for biomedical application is rapidly growing during recent decades, owing to fundamental characteristics of silica, such as size $(5-1000 \mathrm{~nm})$, unique optical properties, high surface area, low density, biocompatibility, low toxicity, adsorption and encapsulation capacity [8]. 
A large group of silica nanoparticles is represented by mesoporous materials, which contain pores with diameters between 2 and $50 \mathrm{~nm}$. Mostly, mesoporous silica nanoparticles (MSN) are synthesised from tetraethyl orthosilicate (TEOS) using template surfactant (often, cetyltrimethylammonium bromide $(\mathrm{CTAB})$ ) as a structure directing agent, which is then removed by solvent extraction, thermal decomposition or calcination [9-11]. Functionalisation of mesoporous silica nanoparticles is of a high interest for controlled release delivery due to their unique properties, which have been summarised by Slowing et al. [12]:

1. Tunable size $(50-300 \mathrm{~nm})$, allowing facile endocytosis by living cells with no significant cytotoxicity;

2. Stable and rigid framework, resistant to degradation induced by heat, $\mathrm{pH}$, mechanical stress or hydrolysis;

3. Uniform and tunable pore size $(2-6 \mathrm{~nm})$, allowing the adjustment and loading of different drug molecules;

4. High surface area and large pore volume, allowing high loading of drug molecules;

5. Two functional surfaces: internal (cylindrical pores) and external (particle surface), allowing selective functionalisation of both;

6. Unique porous structure - honeycomb-like, 2D, hexagonal porous structure with cylindrical pores and no interconnectivity between individual porous channels, providing noleaking capability.

This makes silica nanoparticles promising for their biomedical applications: drug, gene delivery and bioimaging. However, as prospectives of silica nanoparticles in biomedicine has been recognized just recently, along with the great opportunities for their application, there are a lot of challenges to be overcome. This short communication addresses major opportunities, challenges and omissions in the development of silica-based systems for biomedical application.

Synthesis of mesoporous silica nanoparticles. The non-porous silica nanoparticles are synthesized using traditional Stober method with a controlled size in laboratory conditions [13]. Up to today, this route remains the most widely used synthetic approach to synthesize monodispersed silica nanoparticles. TEOS is the most widely-employed silica source for synthesising organosilica nanoparticles [14]. However, the absence of reactive functional groups on their surfaces requires additional modification prior to any further functionalisation. This is often done by the attachment of organosilanes onto silica, providing amino- [15], mercapto- [16], vinyl- [17] and some other functional groups, which enables further conjugation of silica nanoparticles. To avoid an additional step of functionalization in a synthetic procedure of silica nanoparticles, a few successful attempts in the development of a one-pot synthetic approach using various silica sources with functional groups on the surface have been undertaken [18-20]. The vast majority of studies on silica nanoparticles use the Stober synthetic method or its modified versions. For the first time, Irmukhametova et al. [21] reported the formation of sub$100 \mathrm{~nm}$ organosilica nanoparticles from (3-mercaptopropyl)trimethoxysilane (MPTS) in aprotic solvent using a one-pot synthesis (Figure 1). These nanoparticles exhibited a number of thiolgroups available for further conjugation with polymer molecules and fluorescent dyes, their properties have been investigated and reported [22-26]. 

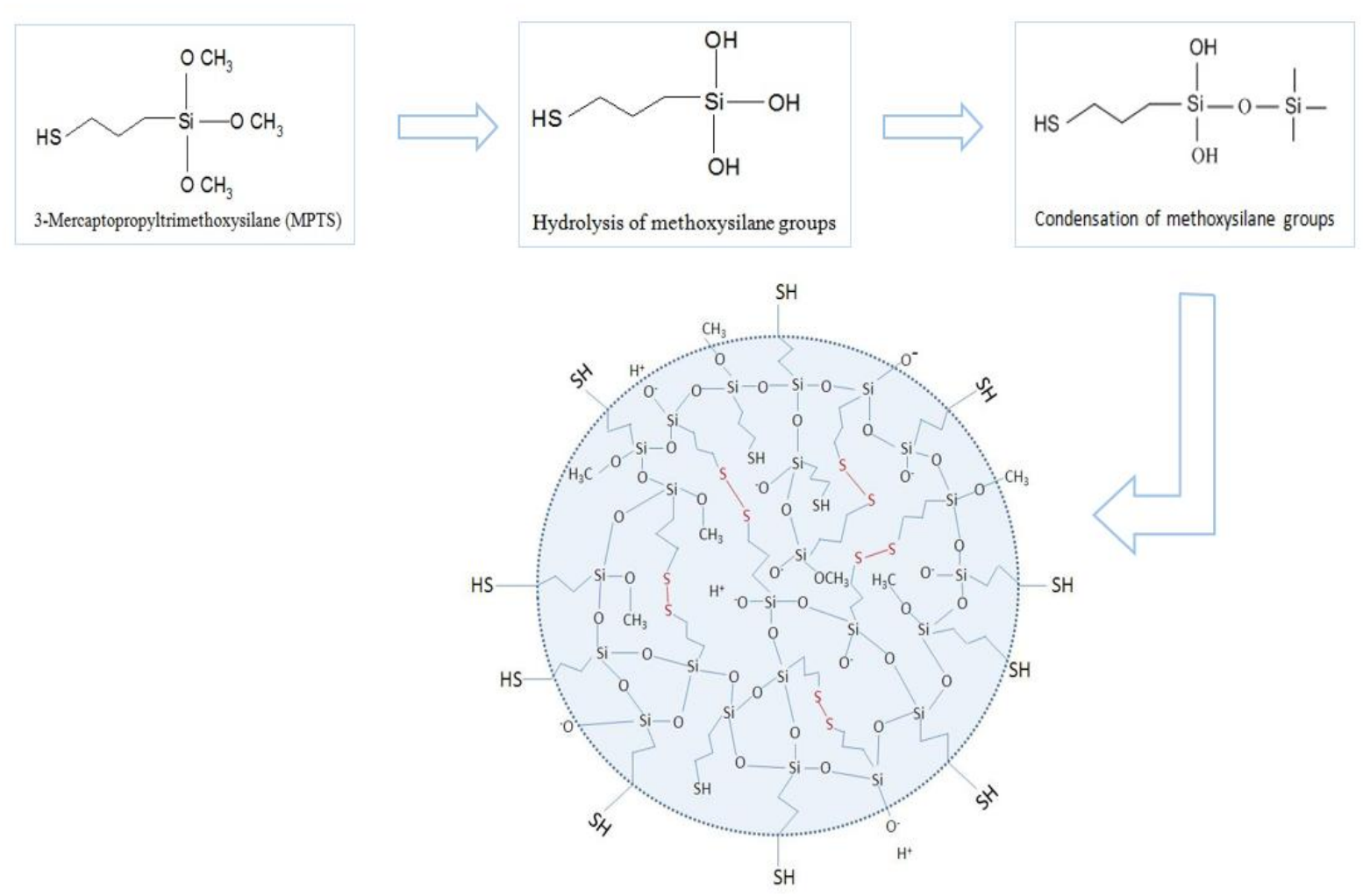

Fig. 1. Three main stages of MPTS nanoparticle formation and the proposed structure of MPTS nanoparticle

If non-porous silica could be synthesized from TEOS and other silica sources, mesoporous organosilica nanoparticles can only be produced using TEOS. Usually, mesoporous silica materials are synthesized employing a surfactant-templated method. During the synthesis, the hydrolysis and following polycondensation of silica source proceeds around the micelles of structure-directing agent (surfactant, often cetyltrimethylammonium bromide) [27]. Many research groups reported the successful synthesis of sub-micron mesoporous silica nanoparticles $[28,29]$. However, there are two aspects that still need to be addressed:

1. As the synthesis is conducted using TEOS, additional step of functionalization is required to enable further modification (attachment of fluorescent dyes, active molecules). To the best of our knowledge, there has been no synthetic protocols on preparation of mesoporous silica nanoparticles from (3-mercaptopropyl)trimethoxysilane, (3-aminopropyl)triethoxysilane or any other silica compounds carrying a functional group published so far. Therefore, further investigation on synthesis of mesoporous silica nanoparticles from different compounds is of a high importance.

2. The size distribution of mesoporous silica nanoparticles synthesized from TEOS using CTAB is not precisely monomodal. According to the protocols published, the size of produced mesoporous TEOS nanoparticles may range from $100 \mathrm{~nm}$ to $1 \mu \mathrm{m}$ in one batch. This makes it challenging not only to perform proper characterization of a synthesized material, but also provides certain difficulties in their direct application. For example, when applied as the drug delivery systems, uniform size is one of the crucial parameters, as it identifies the drug release kinetics. Therefore, it is necessary to optimize the synthetic protocols of mesoporous silica nanoparticles from TEOS or other silica sources. Transmission electron microscopy pictures of mesoporous silica nanoparticles, synthesised from TEOS, are presented below (Figure 2). 

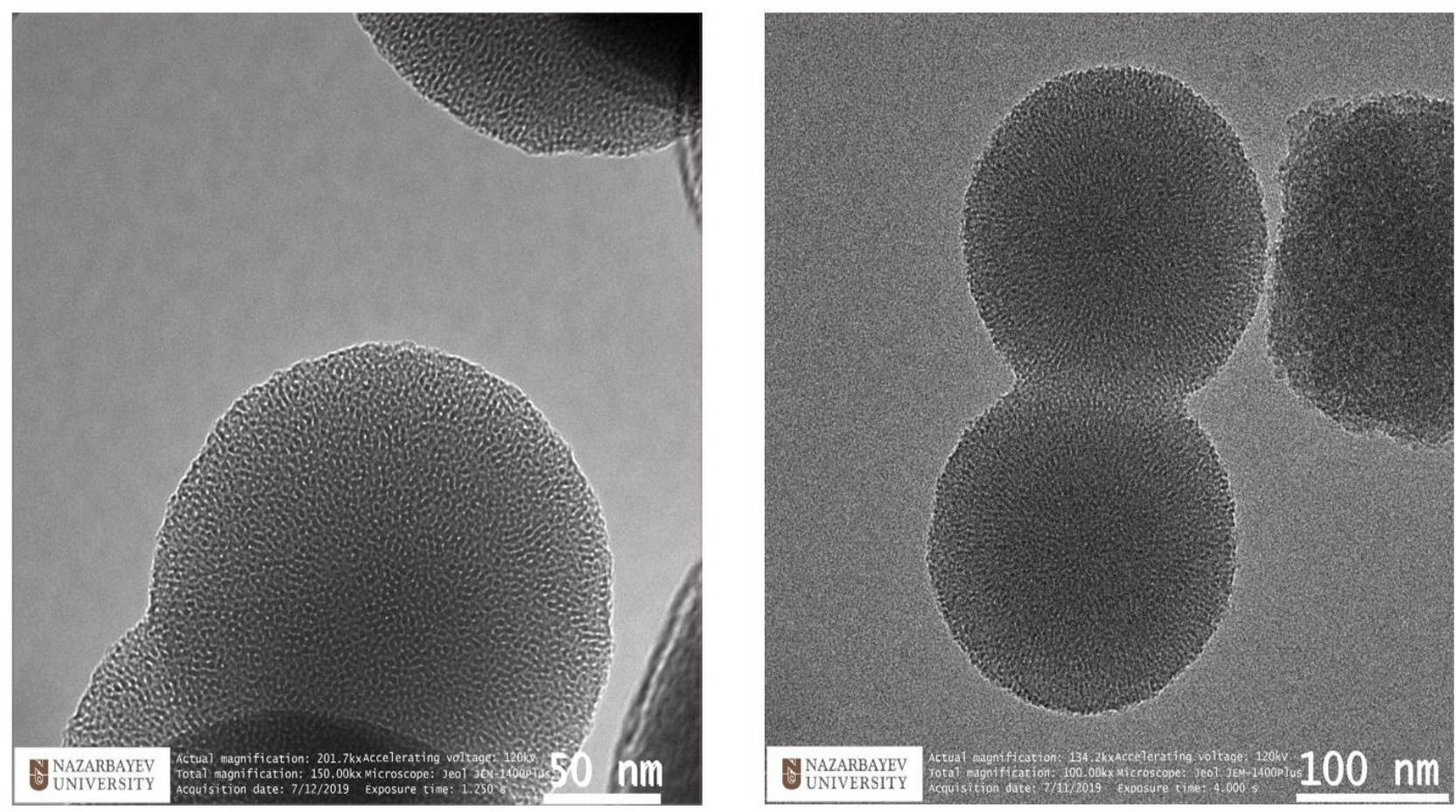

Fig.2. Transmission electron microscopy images of mesoporous silica nanoparticles synthesised from TEOS.

Drug and gene delivery. Upon administering to the body, to avoid an undesirable interaction of a drug with the healthy tissues or cells, it is required to deliver and maintain the effective concentrations of a drug at its targeted site. Another point to address is that hydrophobic drugs cannot be administered directly due to their poor solubility in water. These relate to Class II (low solubility and high permeability) and Class IV (low solubility, low permeability) drugs [30]. Anticancer drugs are one of the representatives of the group. Therefore, to achieve effective drug administration, it is vital to develop the drug delivery systems, preserving the drug from premature release and enabling the selective drug delivery.

The nano-form of mesoporous silica particles has gained a high interest for the pharmaceutical science, where they demonstrate a great potential as nano-drug delivery systems. Due to the unique properties (controllable size, large surface area and pore volume, surface functionalization capabilities), mesoporous silica nanoparticles meet the requirements of the efficient drug delivery system which were summarized by Tiwari and Tiwari [31]:

1. Biocompatibility of the nano-carrier

2. High loading/encapsulation capacity

3. Controlled drug release

4. Targeted drug delivery capability

For the successful drug loading into the carrier (nanoparticle), it is essential that the cargo (drug molecules) retains in the carrier and only releases upon reaching the targeted site in the body. Mesoporous silica nanoparticles are of a particular interest for the delivery of Class II and IV drugs, as they can improve dissolution rates of water poorly soluble drugs [32]. Different research groups have been studying and improving the morphology (size and shape) of MSN, their pore size and functionalization of their surfaces, as these properties determine the capabilities of the material as the drug carrier. The properties of MSN are unique and attractive to make a drug delivery system due to the following factors: a large surface area of MSN ensures a large surface to be exposed to the drug for adsorption; high pore volume allows the loading of a large amount of drug; the presence of silanol groups on the surface allows further functionalization for targeted drug delivery; ordered porous structure, tunable size and nanoparticle monodispersity ensures reproducibility. 
Different research groups are working on improving the properties of MSN, their solubility, bioavailability, pharmacokinetics. Thus, there is a number of studies applying MSN for the delivery of doxorubicin [33-35], lidocaine [36], transplatin [37]. The results demonstrated that MSN loaded with doxorubicin provided better cytotoxicity, selective drug delivery, which makes them promising to improve the efficacy of chemoterapeutic drugs.

A newly emerging application of silica nanoparticles in gene transfection attracts much attention in recent years. Due to the instability of genetic material to be transfected, it should be protected from cell defence mechanisms. Many delivery methods have been developed which can be divided into two main groups: viral and non-viral vectors. While viral delivery systems have significant disadvantages such as nonspecificity immunogenicity and low packaging capacity [38] inorganic non-viral delivery systems show great potential as they are simple in production, have better biocompatibility and can be modified to reduce toxicity. Among inorganic materials, mesoporous silica nanoparticles show promising potential due to their unique properties [38]. Due to the robust synthesis and modifications, MSNs can be used in the combined delivery of drugs and genetic materials. Cheng et al. developed a co-delivery system of curcumin loaded MSN with adsorbed plasmid RhoG-DsRED/TAT peptide complex (Cur@MSN-RhoG-TAT) to protect from ROS-induced cell damage and promotion of neurite outgrowth. Results showed the therapeutic effect of curcumin in Neuro-2a mouse neural crestderived cells, moreover enhancement of RhoG gene expression and neurite outgrowth [39].

Another synergic application of MSN fabricated by Chen et al., 2019 is a co-delivery of MDR-1 siRNA and doxorubicin. Formulation triggered MCF-7/MDR breast cancer cells to sensitise to doxorubicin which leads to cell toxicity. The process of synthesis can be completed in 10 minutes, and includes the following steps: formulation of physical complex of siRNA and doxorubicin, then the complex used as a surfactant to form si-RNA-doxorubicin based silica nanoparticles by (3-Aminopropyl)trimethoxysilane (APTES), which later condensed via tetraethyl orthosilicate (TEOS) [40].

MSN show more significant advantage for gene delivery and co-delivery of genes and therapeutic agents due to the large pore volume and controlled pore size, which allows easy loading of genetic material as well as a therapeutic agent. Moreover, functionalization of the surface can enhance biocompatibility and facilitate targeting, as well as increase expression [41, 42].

Bioimaging. The necessity to develop a platform for diagnostics and treatment led to the formation of a nanomedicine cluster of multifunctional nanoparticles. The advantage of such nanocomposites is the ability to combine gene/drug delivery and providing contrast for various imaging techniques. Such nanoparticles should be based on a material with well defined mesostructures, reactive surface chemistry and tunable morphology. MSN correspond to these characteristics. Therefore the application of MSN in magnetic resonance imaging, computed tomography imaging, positron emission computed tomography, ultrasound imaging and fluorescence imaging highly explored by various scientific groups worldwide.

Through the use of multifunctional nanoparticles, optical tracking of the cellular pathway of inserted therapeutic agent or transfected gene can be visualised. Such application was used in optical tracking of gene delivery via ORMOSIL (organically modified silica) nanoparticle and further detection of successful transfection and expression. Dye loaded ORMOSIL nanoparticles synthesised by triethoxyvinylsilane (VTES) as a precursor and amino-functionalized by 3aminopropyltriethoxysilane (APTES). The positive charge of amino-functionalized nanoparticles attracts negatively charged DNA molecules, therefore, forming protection from degradation. The successful conjugation of DNA and nanoparticles was shown via fluorescence resonance energy transfer (FRET) (a process where one fluorescent molecule acts as a donor of energy to nearby molecule after excitation) between dye inserted to DNA and dye encapsulated in a nanoparticle. DNA release into the cytoplasm was confirmed by excitation of ethidium monoazide (EMA) dye 
on DNA while the success of transfection was confirmed by the expression of EGFP that was encoded in the vector adsorbed by nanoparticle [43].

However the application of MSN does not limit on optical imaging, gold nanoparticles can be easily enclosed in MSN pores or integrated as a core of nanoparticles that can be applied in computer tomography (CT) imaging of hepatocellular carcinoma [44] or liver cancer [45]. Another promising application of multifunctional MSN in T2-weighted tumour diagnosis is coating of superparamagnetic crystals to enhance favourable magnetic resonance imaging (MRI) capabilities, improve the stability in aqueous solutions, prolong life-time, increase biocompatibility, moreover MSN coated nanoparticles showed increased tumour accumulation due to the surface modifications [46]. Figure 3 summarises possible applications of mesoporous silica nanoparticles in biomedicine.

\section{Drug delivery \\ Anticancer, antibiotics, etc. \\ Multifunctional \\ Drug/gene delivery + diagnostics}

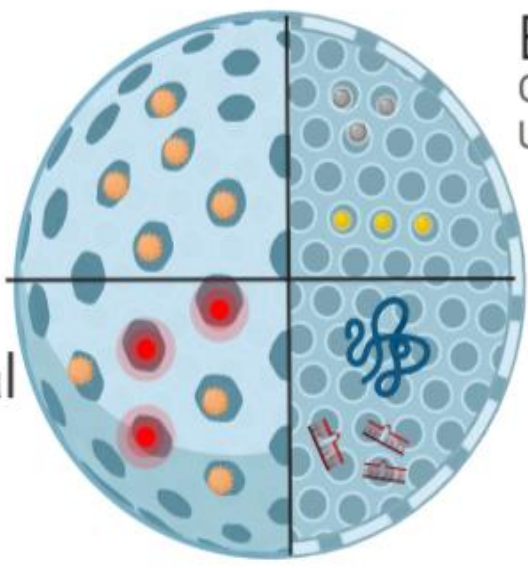

Bioimaging $\mathrm{CT}$, MRI, Ultrasound

Gene and protein delivery

RNA, DNA, peptides
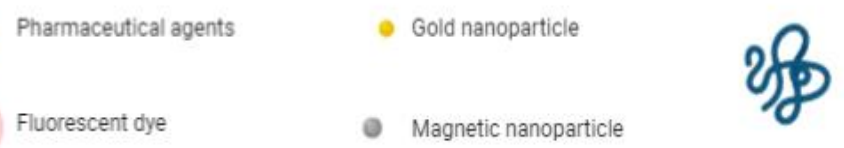

Protein

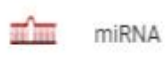

Fig. 3. Application of Mesoporous silica nanoparticles in biomedicine

Biocompatibility. When designing a drug delivery system, it is of a vital importance to study its biocompatibility. According to the International Union of Pure and Applied Chemistry (IUPAC), biocompatibility is the "the ability to be in contact with a living organism without producing an adverse effect" [47]. Silica materials are generally recognised as "Safe" by the USA Food and Drug Administration (FDA), and Cornell dots (C dots) received approval for stage I clinical trials for molecular imaging by FDA [38].

Advanced chemical and physical properties of silica nanoparticles such as large-scale production, large surface to volume ratio, surface reactivity, tunable pore formation and size control brought the use of these nanoparticles not only in medicine but in cosmetics and food products [48]. However there is a lack of full information regarding the interaction of MSN with biological systems. Recent studies publish various toxicity data; therefore, effect of silica nanoparticles on human health remains unclear. Despite the differing data, many agree that the size, functionalization and shape of nanoparticles have a direct effect on toxicity. Besides, silica nanoparticles can be divided into crystalline and amorphous nanoparticles. Crystalline nanoparticles are associated with silicosis (fibronodular lung disease) in mining workers [49], 
while amorphous silica's effect on human is still unclear. Recent publications show cytotoxicity of amorphous colloidal silica nanoparticles in vitro via induction of oxidative stress which mediated apoptosis in size and concentration-dependent pathway. Also, some nanoparticles were able to introduce disturbances of membrane integrity which also led to cytotoxicity. Overall, small-sized nanoparticles $10-20 \mathrm{~nm}$ showed higher toxicity compared to nanoparticles of bigger size (more than 50nm) [50]. Nanoparticles of 50, 100 and $150 \mathrm{~nm}$ sizes show less cytotoxicity in human corneal epithelial cells and no damage in cell membrane integrity than smaller nanoparticles of $20 \mathrm{~nm}$ in size [51]. Although it is challenging to draw complete conclusions from the data, as the concentrations of nanoparticles were higher that caused overload of nanoparticles within cells. In vivo studies on rats and mice showed that nanoparticles administered orally and dermally has no toxicity regardless of shape and size, compared to nanoparticles administered via intravenous, inhalation or ingestion routes. Most of the administered nanoparticles cleared through faeces and urine. However, it is difficult to conclude that the concentration of administered nanoparticles was higher compared to human inhalation exposures [50]. In other works, no cytotoxicity and apoptosis were shown on nanoparticles grafted with chitosan and polyethyleneglycol [52]. Additionally, although silica nanoparticles are often referred to as "highly biocompatible", there is a lack of data on their hemocompatibility [30]. To develop a silica-based nanosystem for intravenous drug delivery, it is essential to study their compatibility with the blood stream as well.

Overall, there is no direct evidence of toxicity of MSN, nor there is enough data informing about the effects of silica nanoparticles on human health.

\section{CONCLUSION}

Today, many research groups are working on improving the properties of mesoporous silica nanoparticles, closing the gaps in the knowledge present so far about them, studying their morphologies, biocompatibility, pharmacokinetics, degradation, drug loading and release, cytotoxicity, blood circulation lifetime, to advance the development and application of MSN from a bench top to a large scale production. Additionally, standartization of silica-based drug delivery system is required to ensure reproducibility. Despite some data lacking on the performance or standartization of mesoporous silica nanoparticles, they possess a high potential for pharmaceutical science as drug delivery systems. Further investigations and crossdisciplinary collaborations are necessary to continuous study of MSN to develop their potential as nano-drug delivery systems, to contribute to human health and personalized medicine.

\section{Acknowledgements}

This work was supported by the Science Committee of the Ministry of Education and Science of the Republic of Kazakhstan (AP05135436, registration No. 0118PK00908). 


\section{REFERENCES}

1. Zhang L., Gu F.X., Chan J.M., Wang A.Z., Langer R.S., Farokhzad O.C. Nanoparticles in medicine: therapeutic applications and developments. Clinical Pharmacology and Therapeutics, 2008, vol. 83, pp. 761-769. PMID: 17957183.

2. Thanh N.T.K. and Green L.A.W. Functionalisation of nanoparticles for biomedical applications. Nano Today, 2010, vol. 5, pp. 213-230. doi: 10.1016/j.nantod.2010.05.003.

3. Jalali N., Moztarzadeh F., Mozafari M., Asgari S., Motevalian M., Alhosseini S.N. Surface modification of poly(lactide-co-glycolide) nanoparticles by d- $\alpha$-tocopheryl polyethylene glycol 1000 succinate as potential carrier for the delivery of drugs to the brain. Colloids and Surfaces A: Physicochem. Eng. Aspects, 2011, vol. 392, pp. 335-342. doi: 10.1016/j.colsurfa.2011.10.012.

4. Canfarotta F., Whitcombe M.J., Piletsky S.A. Polymeric nanoparticles for optical sensing. Biotechnology Advances, 2013, vol. 31, pp. 1585-1599. PMID: 23968893.

5. Jo J., Aoki I., Tabata Y. Design of iron oxide nanoparticles with different sizes and surface charges for simple and efficient labeling of mesenchymal stem cells. Journal of Controlled Release, 2010, vol. 142, pp. 465-473. doi: 10.3390/ijms140918682.

6. Fadeel B. and Garcia-Bennett A.E. Better safe than sorry: Understanding the toxicological properties of inorganic nanoparticles manufactured for biomedical applications. Advanced Drug Delivery Reviews, 2010, vol. 62, pp. 362-374. PMID: 19900497.

7. Jurkić, L. M., Cepanec, I., Pavelić, S. K. \& Pavelić, K. Biological and therapeutic effects of ortho-silicic acid and some ortho-silicic acid-releasing compounds: New perspectives for therapy. Nutrition \& Metabolism, 2013, vol. 10, pp. 1-12. doi: 10.1186/1743-7075-10-2.

8. Bitar A., Ahmad N.M., Fessi H., Elaissari A. Silica-based nanoparticles for biomedical applications. Drug Discovery Today, 2012, vol. 17, pp. 1147-1154. PMID: 22772028.

9. Hu Q., Hampsey J.E., Jiang N., Li C., and Lu Y. Surfactant-templated organic functionalized mesoporous silica with phosphino ligands. Chemistry of Materials, 2005, vol. 17, pp. 1561-1569. doi: 10.1021/cm0491983.

10. Ohkubo T., Ogura T., Sakai H., Abe M. Synthesis of highly-ordered mesoporous silica particles using mixed cationic and anionic surfactants as templates. Journal of Colloid and Interface Science, 2007, vol. 312, pp. 42-46. doi: 10.1016/j.jcis.2007.02.043.

11. Nandiyanto A.B.D., Kim S-G., Iskandar F., Okuyama K. Synthesis of spherical mesoporous silica nanoparticles with nanometer-size controllable pores and outer diameters. Microporous and Mesoporous Materials, 2009, vol. 120, pp. 447-453. doi: 10.1016/j.micromeso.2008.12.019.

12. Slowing I.I., Vivero-Escoto J.L., Wu C-W., Lin V.S-Y. Mesoporous silica nanoparticles as controlled release drug delivery and gene transfection carriers. Advanced Drug Delivery Reviews, 2008, vol. 60, pp. 1278-1288. doi: 10.1016/j.addr.2008.03.012.

13. Stober, W. \& Fink, A. Controlled Growth of Monodispersed Silica Spheres in the Micron Size Range. Journal of Colloid and Interface Science, 1968, vol. 26, pp. 62-69. doi: 10.1016/0021-9797(68)90272-5.

14. Green D.L., Lin J.S, Lam Y-F., Hu M.Z.-C., Schaefer D.W., and Harris M.T. Size, volume fraction, and nucleation of Stober silica nanoparticles. Journal of Colloid and Interface Science, 2003, vol. 266, pp. 346-358. PMID: 14527458.

15. Karimi M., Chaudhury I., Jianjun C., Safari M., Sadeghi R., Habibi-Rezaei M., Kokini J. Immobilization of endo-inulinase on non-porous amino functionalized silica nanoparticles. Journal of Molecular Catalysis B: Enzymatic, 2014, vol. 104, pp. 48-55. doi: 10.1016/j.molcatb.2014.01.025.

16. Takeda Y., Komori Y., Yoshitake H. Direct stober synthesis of monodisperse silica particles functionalized with mercapto-, vinyl- and aminopropylsilanes in alcohol-water mixed solvents. Colloids and Surfaces A: Physicochem. Eng. Aspects, 2013, vol. 422, pp. 68-74. doi: 10.1016/j.colsurfa.2013.01.024. 
17. Effati E., Pourabbas B. One-pot synthesis of sub-50 nm vinyl- and acrylate-modified silica nanoparticles. Powder Technology, 2012, vol. 219, pp. 276-283. doi: 10.1016/j.powtec.2011.12.062.

18. Nakamura M. and Ishimura K. One-pot synthesis and characterization of three kinds of thiol-organosilica nanoparticles. Langmuir, 2008, vol. 24, pp. 5099-5108. PMID: 18366224.

19. Doura, T., Tamanoi, F. and Nakamura, M. Miniaturization of thiol-organosilica nanoparticles induced by an anionic surfactant. Journal of Colloid and Interface Science, 2018, vol. 526, pp. 51-62. PMID: 29715615.

20. Nakamura M. and Ishimura K. Size-controlled, one-pot synthesis, characterization, and biological applications of epoxy-organosilica particles possessing positive zeta potential. Langmuir, 2008, vol. 24, pp. 12228-12234. doi: 10.1021/la801950q.

21. Irmukhametova G.S., Mun G.A., Khutoryanskiy V.V. Thiolated mucoadhesive and PEGylated non-mucoadhesiveorganosilica nanoparticles from 3mercaptopropyltrimethoxysilane. Langmuir, 2011, vol. 27, pp. 9551-9556. PMID: 21707076.

22. Mun E.A., Hannell C., Rogers S.E., Hole P., Williams A.C., Khutoryanskiy V.V. On the role of specific interactions in the diffusion of nanoparticles in aqueous polymer solutions. Langmuir, 2014, vol. 30, pp. 308-317. doi: 10.1021/la4029035.

23. Mun E.A., Morrison P.W.J., Williams A.C., Khutoryanskiy V.V. On the barrier properties of the cornea: a microscopy study of the penetration of fluorescently labeled nanoparticles, polymers and sodium fluorescein. Molecular Pharmaceutics, 2014, vol. 11, pp. 3556-3564. doi: 10.1021/mp500332m.

24. Mansfield, E. D. H., Pandya Y., Mun E.A., Rogers S.E., Abutbul-Ionita I., Danino D., Williams A.C. and Khutoryanskiy V.V. Structure and characterisation of hydroxyethylcellulosesilica nanoparticles. RSC Advances, 2018, vol. 8, pp. 6471-6478. doi: 10.1039/c7ra08716k.

25. Mun E.A., Williams A.C., Khutoryanskiy V.V. Adhesion of thiolated silica nanoparticles to urinary bladder mucosa: effects of PEGylation, thiol content and particle size. International Journal of Pharmaceutics, 2016, vol. 512, pp. 32-38. doi: 10.1016/j.ijpharm.2016.08.026.

26. Al Mahrooqi, J. H., Mun, E. A., Williams, A. C. \& Khutoryanskiy, V. V. Controlling the Size of Thiolated Organosilica Nanoparticles. Langmuir, 2018, vol. 34, pp. 8347-8354. doi: 10.1021/acs.langmuir.8b01556.

27. Diab R., Canilho N., Pavel I.A., Haffner F.B., Girardon M., Pasc A. Silica-based systems for oral delivery of drugs, macromolecules and cells. Advances in Colloid and Interface Science, 2017, vol. 249, pp. 346-362. doi: 10.1016/j.cis.2017.04.005.

28. Trewyn, B. G., Slowing, I. I., Chen, H. and Lin, V. S. Synthesis and Functionalization of a Mesoporous Silica Nanoparticle Based on the Sol - Gel Process and Applications in Controlled Release. Accounts of Chemical Research, 2007, vol. 40, pp. 846-853. doi: 10.1021/ar600032u.

29. Vazquez N.I., Gonzalez Z., Ferrari B., Castro Y Synthesis of mesoporous silica nanoparticles by sol-gel as nanocontainer for future drug delivery applications. Ceramica $y$ Vidrio, 2017, vol. 56, pp. 139-145. doi: 10.1016/j.bsecv.2017.03.002.

30. Karaman, D. Ş. and Kettiger H. Silica-based nanoparticles as drug delivery systems: Chances and challenges. Inorganic Frameworks as Smart Nanomedicines, 2018. doi:10.1016/B978-0-12-813661-4.00001-8.

31. Tiwari, A. and Tiwari, A. Nanomaterials in Drug Delivery, Imaging, and Tissue Engineering, 2013. doi: 10.1002/9781118644591.

32. Van Speybroeck M., Barillaro V., Thi T.D., Mellaerts R., Martens J., Van Humbeeck J., Vermant J., Annaert P., Van den Mooter G., Augustijns P. Ordered Mesoporous Silica Material SBA-15: A Broad-Spectrum Formulation Platform for Poorly Soluble Drugs. Journal of Pharmaceutical Science, 2009, vol. 98, pp. 2648-2658. doi: 10.1002/jps.21638.

33. Li J., Du X., Zheng N., Xu L., Xu J., Li S. Contribution of carboxyl modified chiral mesoporous silica nanoparticles in delivering doxorubicin hydrochloride in vitro: $\mathrm{pH}$-response 
controlled release, enhanced drug cellular uptake and cytotoxicity. Colloids Surfaces B Biointerfaces, 2016, vol. 141, pp. 374-381. doi: 10.1016/j.colsurfb.2016.02.009.

34. Velusamy, P., Srinivasa C.M., Kumar G.V., Qurishi Y., Su C., Gopinath S.C.B. A pH stimuli thiol modified mesoporous silica nanoparticles: Doxorubicin carrier for cancer therapy. Journal of the Taiwan Institute of Chemical Engineers, 2018, vol. 87, pp. 264-271. doi: 10.1016/j.jtice.2018.03.048.

35. Menard M., Meyer F., Parkhomenko K.,Leuvrey C., Francius G., Begin-Colin S., Mertz D. Mesoporous silica templated-albumin nanoparticles with high doxorubicin payload for drug delivery assessed with a 3-D tumor cell model. Biochimica et Biophysica Acta, 2019, vol. 1863, pp. 332-341. doi: 10.1016/j.bbagen.2018.10.020.

36. Nafisi S., Samadi N., Houshiar M., Maibach H.I. Mesoporous silica nanoparticles for enhanced lidocaine skin delivery. International Journal of Pharmaceutics, 2018, vol. 550, pp. 325-332. doi: 10.1016/j.ijpharm.2018.08.004.

37. Tao Z., Toms B., Goodisman J., Asefa T. Mesoporous silica microparticles enhance the cytotoxicity of anticancer platinum drugs. ACS Nano, 2010, vol. 4, pp. 789-794. doi: $10.1021 / \mathrm{nn} 9015345$.

38. Zhou Y., Quan G., Wu Q., Zhang X., Niu B., Wu B., Huang Y., Pan X., Wu C. Mesoporous silica nanoparticles for drug and gene delivery. Acta Pharmaceutica Sinica B, 2018, vol. 8, no. 2, pp. 165-177. doi: 10.1016/j.apsb.2018.01.007.

39. Cheng C.S., Liu T.P., Chien F.C, Mou C.Y., Wu S.H., Chen Y.P. Codelivery of Plasmid and Curcumin with Mesoporous Silica Nanoparticles for Promoting Neurite Outgrowth. ACS Applied Materials and Interfaces, 2019, vol. 11, pp. 15322-15331. doi: 10.1021/acsami.9b02797.

40. Chen M., Wang L., Wang F., Li F., Xia W., Gu H., Chen Y. Quick synthesis of a novel combinatorial delivery system of siRNA and doxorubicin for a synergistic anticancer effect. International Journal of Nanomedicine, 2019, vol. 14, pp. 3557-3569. doi: 10.2147/IJN.S198511.

41. Yang, H., Liu, Y., Qiu, Y., Ding, M. \& Zhang, Y. MiRNA-204-5p and oxaliplatinloaded silica nanoparticles for enhanced tumor suppression effect in CD44-overexpressed colon adenocarcinoma. International Journal of Pharmaceutics, 2019, vol. 566, pp. 585-593. doi: 10.1016/j.ijpharm.2019.06.020.

42. Tsai P.H., Wang M.L., Chang J.H., Yarmishyn A.A., Nguyen P.N.N., Chen W., Chien Y., Huo T., Mou C.Y., Chiou S.H. Dual Delivery of HNF4 $\alpha$ and Cisplatin by Mesoporous Silica Nanoparticles Inhibits Cancer Pluripotency and Tumorigenicity in Hepatoma-Derived CD133Expressing Stem Cells. ACS Applied Materials and Interfaces. 2019, vol. 11, pp. 19808-19818. doi: 10.1021/acsami.9b04474.

43. Roy I., Ohulchanskyy T.Y., Bharali D.J., Pudavar H.E., Mistretta R.A., Kaur N., Prasad P.N. Optical tracking of organically modified silica nanoparticles as DNA carriers: A nonviral, nanomedicine approach for gene delivery. Proceedings of the National Academy of Science U.S.A., 2005, vol. 102, pp. 279-284. doi: 10.1073/pnas.0408039101.

44. Wang Z., Shao D., Chang Z., Lu M., Wang Y., Yue J., Yang D., Li M., Xu Q., Dong W. Janus Gold Nanoplatform for Synergetic Chemoradiotherapy and Computed Tomography Imaging of Hepatocellular Carcinoma. ACS Nano, 2017, vol. 11, pp. 12732-12741. doi: 10.1021/acsnano.7b07486.

45. Wu X., Li L., Zhang L., Wang T., Wang C., Su Z. Multifunctional spherical gold nanocluster aggregate@polyacrylic acid@mesoporous silica nanoparticles for combined cancer dual-modal imaging and chemo-therapy. Journal of Materials Chemistry B, 2015, vol. 3, pp. 2421-2425. doi: 10.1039/c4tb02009j.

46. Yu, L., Lin, H., Lu, X. \& Chen, Y. Multifunctional Mesoporous Silica Nanoprobes: Material Chemistry-Based Fabrication and Bio-Imaging Functionality. Advanced Therapeutics, 2018, vol. 1, pp. 1800078 (1-20). doi: 10.1002/adtp.201800078. 
47. Vert M., Doi Y., Hellwich K., Hess M., Hodge P., Kubisa P., Rinaudo M., Schue F. Terminology for biorelated polymers and applications (IUPAC Recommendations 2012). Pure and Applied Chemistry, 2012, vol. 84, pp. 377-410. doi: 10.1351/PAC-REC-10-12-04.

48. Niu M., Zhong H., Shao H., Hong D., Ma T., Xu K., Chen X., Han J., Sun J. ShapeDependent Genotoxicity of Mesoporous Silica Nanoparticles and Cellular Mechanisms. Journal of Nanoscience and Nanotechnology, 2016, vol. 16, pp. 2313-2318. doi: 10.1166/jnn.2016.10928.

49. Leso V., Fontana, L., Romano, R., Gervetti, P. and Iavicoli, I. Artificial stone associated Silicosis: A systematic review. International Journal of Environmental Research and Public Health, 2019, vol. 16, pp. 1-17. doi: 10.3390/ijerph16040568.

50. Murugadoss S., Lison D., Godderis L., Van Den Brule S., Mast J., Brassinne F., Sebaihi N., Hoet P.H. Toxicology of silica nanoparticles: an update. Archives Toxicology, 2017, vol. 91, pp. 2967-3010. doi: 10.1007/s00204-017-1993-y.

51. Park J., Jeong H., Hong J., Chang M., Kim M., Chuck R.S., Lee J.K., and Park C. The Effect of Silica Nanoparticles on Human Corneal Epithelial Cells. Scientific Reports, 2016, vol. 6, pp. 1-11. doi: 10.1038/srep37762.

52. Moodley, T. and Singh, M. Polymeric Mesoporous Silica Nanoparticles for Enhanced Delivery of 5-Fluorouracil In Vitro. Pharmaceutics, 2019, vol. 11, pp. 1-21. doi: 10.3390/pharmaceutics11060288. 


\section{БИОМЕДИЦИНАЛЫҚ КОЛДАНУҒА АРНАЛҒАН \\ КРЕМНИЙЛІ НАНОБӨЛШЕКТЕР: ҚИЫНДЫҚТАР МЕН МУМКІНДІКТЕР}

Мун Э.А., Жайсанбаева Б.А.

Ұлттық биотехнология ортальвы

Қорвалжын тас жоль 13/5, Нұр-Сұлтан, 010000, Қазақстан

ellina.moon@gmail.com

\section{ТYЙІН}

Соңғы бірнеше онжылдықта нанобөлшектері бірегей физика-химиялық қасиеттеріне байланысты химиялық, биомедициналық, фармацевтикалық ғылымдардағы зерттеулерге үлкен назар аударды. Оған ультра кішкентай өлшем, бетінің үлкен ауданы, жақсы биоқосымдылық және жоғары реактивтілік кіреді. Атап айтқанда, нанобөлшектері фармацевтикалық және биомедициналық салалар үшін перспективалы, өйткені оларды дәрі-дәрмек тасымалдаушы және диагностикалық құрал ретінде қолдануға болады. Биомедициналық қолдануға арналған наноматериалдардың ішінде кремнийлі нанобөлшектер олардың тікелей синтезделуі және бөлінуі, төмен құны, қауіпсіздігі, биомассаттылығы және әрі қарай жұмыс істеу мүмкіндігі арқасында үлкен әлеуетке ие. Кремнийлі нанобөлшектері фармацевтика ғылымы үшін біртектес қасиеттерімен, мысалы, реттелетін мөлшері, беткейінің үлкен ауданы және кеуектердің үлкен көлемі, сондай-ақ дәрілік заттар мен генді жеткізу векторлары мен биоимгациялық агенттер ретінде биомедициналық қолдану мүмкіндігінің арқасында тартымды болды. Алайда, олардың кейбір қасиеттері нашар зерттелген. Бұл қысқа байланыс кремнийлі нанобөлшектерді синтездеудің негізгі бағыттарын, олардың қасиеттері мен оларды фармацевтикалық және биомедициналық салада қолдану мүмкіндіктерін, сонымен қатар кремний негізіндегі жүйелерді дамытудағы бірнеше қиындықтарды талқылайды.

Түйін сөздер: кремний, нанобөлшектер, дәрі-дәрмек жеткізу, генді жеткізу, биомедициналық қолдану 


\title{
ОРГАНОКРЕМНЕЗЕМНЫЕ НАНОЧАСТИЦЫ ДЛЯ БИОМЕДИЦИНСКОГО ПРИМЕНЕНИЯ: ПРОБЛЕМЫ И ВОЗМОЖНОСТИ
}

Мун Э.А., Жайсанбаева Б.А.

Наџиональный цеентр биотехнологии

Кургальжинское шоссе, 13/5, Нур-Султан, 010000, Казахстан

ellina.moon@gmail.com

\begin{abstract}
АБСТРАКТ
В последние несколько десятилетий наночастицы привлекают значительное внимание исследователей в области химических, биомедицинских, фармацевтических наук из-за их уникальных физико-химических свойств, таких как: сверхмалые размеры, большая плошадь поверхности, хорошая биосовместимость и высокая реакционная способность. В частности, наночастицы являются перспективными для фармацевтической и биомедицинской областей, поскольку они могут применяться в качестве носителей лекарственных средств и диагностических инструментов. Среди наноматериалов для биомедицинского применения большой потенциал демонстрируют наночастицы диоксида кремния. Они привлекательны для фармацевтической науки благодаря их уникальным свойствам, таким как: контролируемый размер, большая площадь поверхности и большой объем пор, а также потенциал в биомедицинском применении в качестве векторов доставки лекарств и генов, а также агентов для биовизуализации. Однако, некоторые их свойства остаются малоизученными. В данном обзоре рассматриваются основные пути синтеза наночастиц кремнезема, их свойства и возможности их применения В фармацевтической и биомедицинской промышленности, а также некоторые проблемы в разработке систем на основе кремнезема, которые необходимо преодолеть.

Ключевые слова: органокремнезем, наночастицы, доставка лекарств, доставка генов, биомедицинское применение.
\end{abstract}

